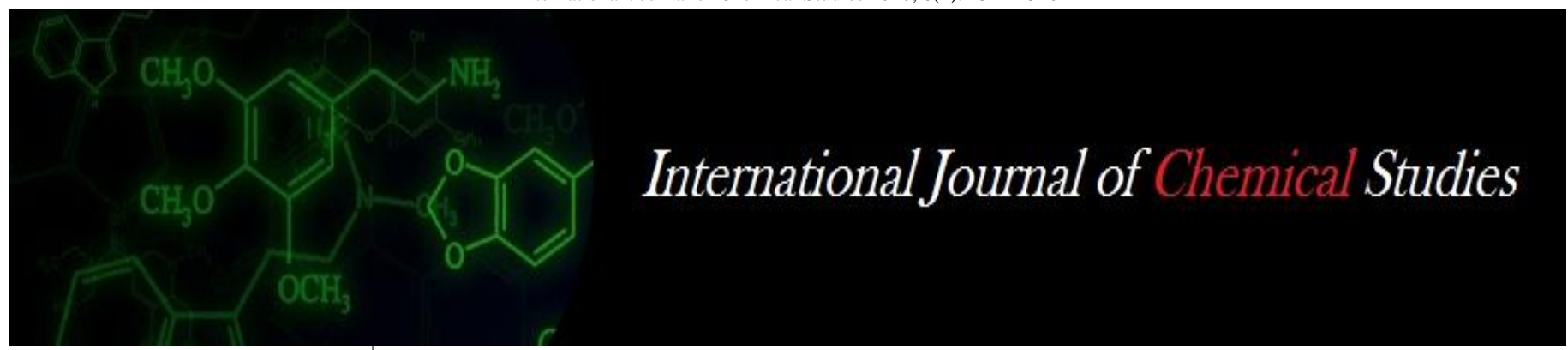

P-ISSN: 2349-8528

E-ISSN: 2321-4902

IJCS 2020; 8(1): 2514-2516

(C) 2020 IJCS

Received: 24-11-2019

Accepted: 26-12-2019

\section{Anoj Yadav}

Department of Horticulture,

School of Agricultural Science and Technology, Babasaheb

Bhimrao Ambedker University,

Lucknow, Uttar Pradesh, India

\section{RB Ram}

Department of Horticulture,

School of Agricultural Sciences and Technology, Babasaheb

Bhimrao Ambedker University,

Lucknow, Uttar Pradesh, India

Rubee Lata

Department of Horticulture,

School of Agricultural Sciences and Technology, Babasaheb

Bhimrao Ambedker University, Lucknow, Uttar Pradesh, India

\section{GC Yadav}

Department of Horticulture,

School of Agricultural Sciences and Technology, Babasaheb

Bhimrao Ambedker University, Lucknow, Uttar Pradesh, India

Corresponding Author:

Anoj Yadav

Department of Horticulture,

School of Agricultural Sciences and Technology, Babasaheb

Bhimrao Ambedker University, Lucknow, Uttar Pradesh, India

\section{Effect of INM on growth, bulb yield and quality of onion (Allium cepa L.) cv. Agrifound Dark Red}

\author{
Anoj Yadav, RB Ram, Rubee Lata and GC Yadav
}

DOI: https://doi.org/10.22271/chemi.2020.v8.i1al.8647

\begin{abstract}
The present experiment was carried out on onion cultivar Agrifound Dark Red during Rabi season 201819 with objective to know the effect of integrated nutrient management (INM) on growth, bulb yield and quality of onion. The experiment was laid out in a randomized block design with three replications. The treatments consisted of $\mathrm{T}_{1}$-Control, $\mathrm{T}_{2}-100 \% \mathrm{NPK}, \mathrm{T}_{3}-75 \% \mathrm{NPK}+$ Azotobactor, $\mathrm{T}_{4}-75 \% \mathrm{NPK}+$ $\mathrm{PSB}, \mathrm{T}_{5}-75 \% \mathrm{NPK}+$ Azotobactor $+\mathrm{PSB}, \mathrm{T}_{6}-50 \% \mathrm{NPK}+$ Azotobactor, $\mathrm{T}_{7}-50 \% \mathrm{NPK}+\mathrm{PSB}, \mathrm{T}_{8}-$ $50 \%$ NPK + Azotobactor + PSB, T9 $-100 \%$ NPK + Vermicompost. Results revealed that application of different levels of fertilizers, viz., organic manures and biofertilizers either alone or in combination significantly increased the growth, bulb yield and quality of onion as compared to control. The maximum bulb yield $(235.483 \mathrm{q} / \mathrm{ha})$ and diameter of bulb $(4.443 \mathrm{~cm})$ were recorded with $100 \% \mathrm{NPK}+$ Vermicompost.
\end{abstract}

Keywords: Onion, integrated nutrient management, chemical fertilizers, organic manures, biofertilizers, growth, bulb yield quality

\section{Introduction}

Onion (Allium cepa L.) is known as "Queen of Kitchen" is one of the most important vegetable grown in India. It belongs to the family Alliaceae and genus Allium is very large comprising of more than 500 species usually perennial bulbous plants. Alliums are among the oldest cultivated plant species. It is consumed as a vegetable and condiment. Green leaves, immature or mature bulbs of onion are eaten as green vegetable. It is indispensible item in every kitchen or condiments and used to enhance flavor of different recipes and hence commands an extensive internal market. The green leaves and immature and mature bulbs are eaten raw or used in preparation of vegetable. On account of its special characteristic of pungency, it is valued much. Onions are used in soups, sauces and for seasoning foods. Attention is given to crispness, Juiciness, pungency and keeping quality of the bulb. The small bulbs and shallots are pickled in vinegar or brine. Dehydrated bulb or onion powder is in great demand which reduces transport cost and storage losses. Dried onion flakes can be reconstituted by cooking in water.

Nutrient management is one of the most important considerations under organic production system. The increasing cost of chemical fertilizers and their harmful effects on the soil health is also an important consideration for the use of organic nutrients (Patel et al., 2005). Average marketable yield of onion is very low as compared to other onion producing countries. One of the reason for low yield is used of inadequate and unbalanced fertilization. So concept of adding bio-fertilizer is required to be adjusted along with judicious combination of chemical and organic fertilizers. In North India, only one crop of onion crop known as late Rabi or summer season is grown widely and it arrives in the market from May to June. It is cultivated in all type of soils but sandy-loam soil is the best. All the recommendations so for noticed are only for the normal soil. Least information is available with regard to nitrogen and potassium fertilization in onion bulb production on semi reclaimed sodic soil under the conditions of Lucknow.

\section{Materials and Methods}

The present experiment entitled was carried out at the Horticulture Research Farm-II, Babasaheb Bhimrao Ambedkar University, Lucknow during Rabi season in 2018-2019. Trial 
was started during the month of October. The seedlings of onion variety were transplanted on 25-12-2018. Geographically, Lucknow is situated at an elevation of 111 meter above mean sea level in the subtropical climate of central Uttar Pradesh at $26.56^{\circ}$ north latitude and $80.52^{\circ}$ East longitudes. The climate of region is subtropical with maximum temperature ranging from $22{ }^{\circ} \mathrm{C}$ to $45{ }^{\circ} \mathrm{C}$ in summer, minimum temperature ranging from 3.5 to $15{ }^{\circ} \mathrm{C}$ in winter and relative humidity ranging from $60-80 \%$ in different seasons of the year.

Before start of the experiment, the represented soil samples were taken randomly in a depth of $0-15 \mathrm{~cm}$ from experimental field and result of soil analysis showed soil texturally classified as loamy sand and slightly alkaline in reaction. Onion seeds of Agri found Dark Red were sown on nursery beds by broadcasting method on raised beds. The healthy and uniform shape and sizes of onion saplings were selected and treated with carbendazim @ 2 g/liter of water then transplanted in prepared field. The required area was then marked with plots size of $1.20 \mathrm{~m} \times 0.975 \mathrm{~m}$ were also prepared and planted at spacing of $15 \times 7.5 \mathrm{~cm}^{2}$.

The experiment was laid out in Randomized Block Design with three replications. The experiment was comprised of 9 treatment combinations of four levels of inorganic fertilizers and four levels of organic manures. The application of different integrated nutrient were applied during Rabi season in 2018-19. The symbol of treatment were $\mathrm{T}_{1}$ Control, $\mathrm{T}_{2}$ $100 \%$ NPK, $\mathrm{T}_{3} 75 \% \mathrm{NPK}+$ Azotobactor, $\mathrm{T}_{4} 75 \% \mathrm{NPK}+$ $\mathrm{PSB}, \mathrm{T}_{5} 75 \% \mathrm{NPK}+$ Azotobactor $+\mathrm{PSB}, \mathrm{T}_{6} 50 \% \mathrm{NPK}+$ Azotobactor, $\mathrm{T}_{7} 50 \% \mathrm{NPK}+\mathrm{PSB}, \mathrm{T}_{8} 50 \% \mathrm{NPK}+$ Azotobactor + PSB, $\mathrm{T}_{9} 100 \%$ NPK + Vermicompost. Observations were recorded on plant height $(\mathrm{cm})$, leaf size $(\mathrm{cm})$, number of leaves $(\mathrm{cm})$, neck thickness $(\mathrm{cm})$, diameter of bulb $(\mathrm{cm})$, bulb length $(\mathrm{cm})$, yield $(\mathrm{q} / \mathrm{ha})$, number of scale and total soluble solids $\left({ }^{0} \mathrm{~B}\right)$ from October to April, 2018-19. Digging was done manually by hand digger. The data were analyzes using analysis of variance (ANOVA) under RBD stated by Fisher (1950) ${ }^{[5]}$.

\section{Results and Discussion}

The data presented in Table-1 clearly indicates that the maximum plant height was recorded in $\mathrm{T}_{8}(69.687 \mathrm{~cm}$.) with application of 50\% NPK + Azotobactor + PSB at 90 DAT and minimum plant height $\left(52.32 \mathrm{~cm}\right.$.) was recorded in $\mathrm{T}_{1}$ control. Similar results were also found by Reddy and Reddy (2005) [7] in their studied on the effects of different levels of vermicompost $\left(0,10,20\right.$ and $\left.30 \mathrm{t} \mathrm{ha}^{-1}\right)$ on growth of onion (cv. N-53). The plant height, number of leaves per plant and leaf area increase significantly with increased levels of vermicompost from 10 to $30 \mathrm{t}$ per ha. Significantly higher plant height, number of seed stalks per plant in onion was recorded with the application of FYM @ 10,15 and $20 \mathrm{t}$ per ha than 5 t per ha (Patil et al., 2007) ${ }^{[6]}$. Similarly Ethel et al. (2009) ${ }^{[4]}$ recorded significantly higher plant height of onion with FYM $30 \mathrm{t}$ per ha. $(30.3-45.2 \mathrm{~cm})$ compared to other organic manure.

Maximum number of leaves per plant (8.823) was observed under the treatment $\mathrm{T}_{8} 50 \% \mathrm{NPK}+$ Azotobactor + PSB at 90 DAT and minimum number of leaves (4.330) was recorded in $\mathrm{T}_{1}$ (control). Varu et al. (1997) ${ }^{[8]}$ and Patil et al. (2007) ${ }^{[6]}$ also found significantly higher number of leaves per plant (6.25) and plant height $(46.70 \mathrm{~cm})$ with NPK 100:50:100 kg per ha over the control. In onion seed crop significantly higher plant height at 60 and 90 DAT and at harvest and significantly higher number of seed stalks per plant with 150:60:30 kg NPK per ha with bio-fertilizers Azospirillum or Phosphobacreria was recorded by Patil et al. (2007) ${ }^{[6]}$.

Maximum leaf length, $(62.393 \mathrm{~cm})$ was recorded with $\mathrm{T}_{5}(75 \%$ $\mathrm{NPK}+$ Azotobactor $+\mathrm{PSB})$ while treatment $\mathrm{T}_{1}$ (control) showed the minimum leaf length $(42.33 \mathrm{~cm})$. Similar results were found also by Chatoo et al. (1997) ${ }^{[3]}$ in case of knolkhol.

Maximum neck thickness $(1.30 \mathrm{~cm})$ at 90 DAT also observed with treatment $\mathrm{T}_{7}(50 \% \mathrm{NPK}+\mathrm{PSB})$, whereas minimum neck thickness $(1.040 \mathrm{~cm})$ was recorded in $\mathrm{T}_{1}$ (control). Similar result were found by Broadbent et al. (1977) ${ }^{[1]}$ in his study in which phosphobacteria provides protection against the nonparasitic root pathogen produces biologically active substances like auxin and gibberellins and transform unavailable mineral and organic compounds into available to the plants, so these effects would have led to increased in growth. The minimum stem diameter was not seen constant among the different treatments at all the growth stages. However, at 90 DAT treatment $\mathrm{T}_{1}$ recommended doses of NPK through chemical fertilizers showed minimum stem diameter in onion crop.

Maximum bulb diameter and bulb length was recorded in $\mathrm{T}_{9}$ $(4.410 \mathrm{~cm} \& 4.443 \mathrm{~cm}) 100 \% \mathrm{NPK}+$ vermicompost showed highest value compared to all other treatment Minimum bulb diameter and bulb length $(3.95 \mathrm{~cm} \& 3.61 \mathrm{~cm})$ were recorded with treatment $\mathrm{T}_{1}$ (control), respectively.

The bulb diameter performance increased significantly when subjected to organic fertilizer (vermicompost). Similar result was also reported by Reddy and Reddy (2005) ${ }^{[7]}$ in their study in Andhra Pradesh (India) to determine the effects of different levels of vermicompost $\left(0,10,20\right.$ and $\left.30 \mathrm{t} \mathrm{ha}^{-1}\right)$ and nitrogen fertilizers $\left(0,50,100,150\right.$ and $\left.200 \mathrm{~kg} \mathrm{ha}^{-1}\right)$ on the growth and bulb yield of onion (cv. N-53).

The bulb length, diameter and weight of onion increased significantly with increasing levels of vermicompost (from 10 to $30 \mathrm{t} \mathrm{ha}^{-1}$ ) and nitrogen fertilizers (from 50 to $200 \mathrm{~kg} \mathrm{ha}^{-1}$ ). Among the various treatments combinations, vermicompost at $30 \mathrm{t}$ per ha $+200 \mathrm{~kg} \mathrm{~N}$ per ha was superior followed by vermicompost at $30 \mathrm{t}$ per ha $+150 \mathrm{~kg} \mathrm{~N}$ per ha in terms of bulb length and bulb height of onion. Significantly higher bulb weight and polar diameter was recorded with the combined application of organic manure (FYM at $10 \mathrm{t} \mathrm{ha}^{-1}$ ) and inorganic fertilizers (NPK at 120:75:60 $\mathrm{kg} \mathrm{ha}^{-1}$ ) compared to other treatments, there results are in conformity with the finding of Chadha et al. (2006) ${ }^{[2]}$.

However, the treatment indicated that treatment $\mathrm{T}_{6}(50 \%$ NPK + Azotobactor) showed highest value of diameter of bulb 4.41 $\mathrm{cm}$ compared to all other treatment while minimum $(3.95 \mathrm{~cm})$ in treatment $\mathrm{T}_{1}$ (control). The maximum number of scales was recorded in treatment $\mathrm{T}_{5}(7.610 / \mathrm{bulb})$ with application of (75\% NPK + Azotobactor + PSB), whereas minimum number of scales was recorded in control plot.

The maximum bulb yield was recorded in $\mathrm{T}_{9}(235.483 \mathrm{q} / \mathrm{ha})$ by application of $100 \%$ NPK + vermicompost and minimum bulb yield was recorded in control plot. Reddy and Reddy (2005) ${ }^{[7]}$ in Andhra Pradesh (India) recorded significantly higher bulb length, diameter and weight of onion with higher levels of vermicompost (from 10 to $30 \mathrm{t} \mathrm{ha}^{-1}$ ) and nitrogen fertilizer (from 50 to $200 \mathrm{~kg} \mathrm{ha}^{-1}$ ) and similarly, Ethel et al. (2009) ${ }^{[4]}$ recorded significantly higher bulb weight of onion with FYM $30 \mathrm{t}$ per ha $\left(40 \mathrm{~g} \mathrm{bulb}^{-1}\right)$ compared to other treatments and control. 
Table 1: Effect of INM on growth and yield attributes on Rabi onion (Allium cepa L.) cv. Agrifound Dark Red

\begin{tabular}{|c|c|c|c|c|c|c|c|c|c|}
\hline Treatments & $\begin{array}{l}\text { Number } \\
\text { of leaves }\end{array}$ & $\begin{array}{c}\text { Plant } \\
\text { Height } \\
\text { (cm) }\end{array}$ & $\begin{array}{c}\text { Length of } \\
\text { leaves } \\
\text { (cm) }\end{array}$ & $\begin{array}{c}\text { Neck } \\
\text { thickness } \\
(\mathrm{cm})\end{array}$ & $\begin{array}{c}\text { Diameter of } \\
\text { bulb }(\mathrm{cm})\end{array}$ & $\begin{array}{l}\text { Length of } \\
\text { bulb }(\mathrm{cm})\end{array}$ & \begin{tabular}{|c|}
$\begin{array}{c}\text { Number } \\
\text { of scales/ } \\
\text { bulb }\end{array}$ \\
\end{tabular} & \begin{tabular}{|c|} 
Total \\
soluble \\
solids $\left({ }^{\circ} \mathbf{B}\right)$ \\
\end{tabular} & $\begin{array}{c}\text { Yield of } \\
\text { fresh } \\
\text { bulb(q/ha) }\end{array}$ \\
\hline $\mathrm{T}_{1}$ Control & 5.313 & 52.320 & 42.393 & 1.040 & 3.950 & 3.610 & 4.253 & 12.9 & 166.410 \\
\hline $\mathrm{T}_{2} 100 \% \mathrm{NPK}$ & 6.520 & 55.340 & 51.710 & 1.157 & 4.287 & 3.857 & 4.653 & 12.5 & 170.853 \\
\hline $\mathrm{T}_{3} 75 \% \mathrm{NPK}+$ Azotobactor & 7.297 & 61.353 & 55.650 & 1.223 & & 4.270 & 5.590 & 12.9 & 174.267 \\
\hline $\mathrm{T}_{4} 75 \% \mathrm{NPK}+\mathrm{PSB}$ & 5.797 & 62.220 & 48.620 & 1.150 & 4.350 & & 6.290 & 15.1 & 186.203 \\
\hline $\mathrm{T}_{5} 75 \% \mathrm{NPK}+$ Azotobactor $+\mathrm{PSB}$ & 6.63 & 65.300 & 62.393 & 1.210 & 4.233 & 3.790 & 7.610 & 13.9 & 227.783 \\
\hline $\mathrm{T}_{6} 50 \% \mathrm{NPK}+$ Azotobactor & 6.18 & 64.583 & 46.540 & 1.223 & 4.410 & 4.407 & 5.557 & 14.4 & 219.537 \\
\hline $\mathrm{T}_{7} 50 \% \mathrm{NPK}+\mathrm{PSB}$ & 7.820 & 68.103 & 51.573 & 1.307 & 4.323 & 3.627 & 6.353 & 12.6 & 199.623 \\
\hline $\mathrm{T}_{8} 50 \% \mathrm{NPK}+$ Azotobactor $+\mathrm{PSB}$ & 8.823 & 69.687 & 58.610 & 1.250 & 4.303 & 4.217 & 5.80 & 11.8 & 203.103 \\
\hline $\mathrm{T}_{9} 100 \% \mathrm{NPK}+$ Vermicompost & 7.250 & 63.353 & 45.117 & 1.210 & 4.330 & 4.443 & 5.197 & 12.7 & 235.483 \\
\hline
\end{tabular}

\section{Conclusion}

On the basis of results emerging out from the present investigation, it can be concluded that combined application of $100 \%$ NPK + Vermicompost is significantly best to get the highest of as bulb yield (235.483 q/ha) in Rabi onion than rest of the treatments during the course of investigation.

\section{References}

1. Broadbent J, Ciancanelli P, Gallhofer S, Haslam J. Enabling accounting: the way forward, Accounting Auditing and Accountability Journal. 1997; 2(1):265-275.

2. Chadha S, Rana SS, Chaudhary DR. Nutrient management in summer onion (Allium cepa L.) under cold desert conditions of North Western Himalayas, Indian J Agric. Sci. 2006; 76(10):629-631.

3. Chatoo MA, Gandroo MY, Zargar MY. Effect of azospirillium and azotobactor on growth, yield and quality of Knolkhol (Brassica oleracia var. gonylodes L.). Vegetable Science. 1997; 24(1):16-19.

4. Ethel, Singh AK, Singh VB. Effect of organic manures and biofertilizers on growth, yield and quality of onion. Environ. Biol. 2009; 27(1A):313-315.

5. Fisher RA. Statistical methods for research workers $\left(11^{\text {th }}\right.$ ed.). Edinburgh, UK: Oliver \& Boyd., 1950.

6. Patil HM, Shete B, Kolekar PT. Effect of integrated nutrient management on growth and yield of onion (Allium cepa L.) seed production. Int. J Agric. Sci. 2007; 3(2):83-86.

7. Reddy KC, Reddy KM. Differential levels of vermicompost and nitrogen on growth and yield in onion (Allium cepa L.), radish (Raphanus sativus L.) cropping system. Journal research ANGRAU. 2005; 33(1):11-17.

8. Varu DK, Vhora PH, Kikani KP. Effect of organic and inorganic fertilizers on onion. Gujarat Agric. Univ. J 1997; 22(2):116-118. 